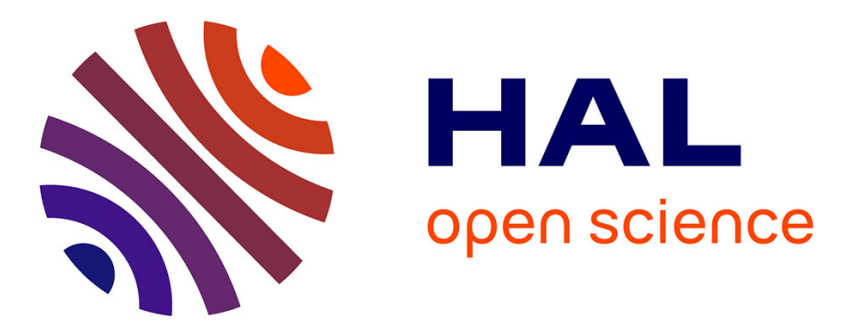

\title{
Excited-state luminescence properties and laser performance of the Tm3+ doped perovskite YAlO3
}

H. Manaa, V. Wiedeman, R. Moncorgé, M. Koselja, J. Souriau

\section{To cite this version:}

H. Manaa, V. Wiedeman, R. Moncorgé, M. Koselja, J. Souriau. Excited-state luminescence properties and laser performance of the Tm3+ doped perovskite YAlO3. Journal de Physique IV Proceedings, 1994, 04 (C4), pp.C4-525-C4-528. 10.1051/jp4:19944126 . jpa-00252577

\section{HAL Id: jpa-00252577 https://hal.science/jpa-00252577}

Submitted on 1 Jan 1994

HAL is a multi-disciplinary open access archive for the deposit and dissemination of scientific research documents, whether they are published or not. The documents may come from teaching and research institutions in France or abroad, or from public or private research centers.
L'archive ouverte pluridisciplinaire HAL, est destinée au dépôt et à la diffusion de documents scientifiques de niveau recherche, publiés ou non, émanant des établissements d'enseignement et de recherche français ou étrangers, des laboratoires publics ou privés. 


\title{
Excited-state luminescence properties and laser performance of the $\mathrm{Tm}^{3+}$ doped perovskite $\mathrm{YAIO}_{3}$
}

\author{
H. MANAA, V. WIEDEMAN, R. MONCORGÉ, M. KOSELJA* and J.C. SOURLAU**
}

LPCML, Université de Lyon I, URA 442 du CNRS, 69622 Villeurbanne, France

${ }^{*}$ PRECIOSA S.A., Turnov, Tcheque Republic

${ }^{* *}$ LETI/CEA-Tech. Avancées, DOPT-SMDO CENG 85X, 38041 Grenoble, France

\section{Introduction}

Polarized absorption and emission spectra have been recorded in a broad spectral range to determine the best pumping and laser emission conditions of the crystals in the infrared domain and to show their potentialities in the blue/green and red regions. These data are completed by lifetime measurements made as a function of the dopant concentration and a discussion of the radiative versus the non-radiative relaxations between the various excited-states is developed on the basis of the Judd-Ofelt formalism. Ponctual excited-state excitation/absorption measurements are also performed to derive cross section values in a spectral region which has been found [1] interesting in this material for photon-avalanche up-conversion.

\section{Experimental results}

Figure 1a and 1b show the room temperature polarized absorption spectra of a YAP crystal doped by about $5 \% \mathrm{Tm}^{34}$ ions. According to Weber [2] these spectra lead to the Judd-Ofelt parameters:

$$
\Omega_{2}=0.67 \times 10^{-20} \mathrm{~cm}^{2}, \Omega_{4}=2.3 \times 10^{-20} \mathrm{~cm}^{2}, \Omega_{6}=0.74 \times 10^{-20} \mathrm{~cm}^{2}
$$

which give in turn the radiative lifetimes and branching ratios given in Table 1.

Figures 2 and 3 show the room temperature visible emission spectra of a $1 \% \mathrm{Tm}^{3+}$ doped powder sample obtained after $\mathrm{D}_{2}$ and $\mathrm{G}_{4}$ excitations at 355 and $470 \mathrm{~nm}$ respectively. These spectra show the spectral extents and give an idea of the respective intensities of the transitions originating from the ${ }^{1} \mathrm{D}_{2}$ and ${ }^{1} \mathrm{G}_{4}$ and terminating on the ${ }^{3} \mathrm{H}_{6}$ and ${ }^{3} \mathrm{~F}_{4}$ levels.

Figure 4 gives the room temperature polarized emission spectra of a $5 \%$ $\mathrm{Tm}^{3+}$ doped crystal as a function of polarization, the spectra being calibrated between each other.

Table 2 gives the room temperature 1/e fluorescence time constants of the emissions originating from the various energy levels as a function of the dopant concentration.

In the end we give in Figures $5 \mathrm{a}$ and $5 \mathrm{~b}$ room temperature polarized excited state excitation (ESE) spectra which were recorded with the aid of a two beam experiment, one laser beam being used to bring the ions in 
their ${ }^{3} \mathrm{H}_{4}$ excited state, after pumping of the ${ }^{3} \mathrm{~F}_{2},{ }^{3} \mathrm{~F}_{3}$ levels and multiphonon relaxation, and the other, which could be triggered at various time delays after the former, being used to probe the fluorescences coming from the ${ }^{D_{2}}$ and ${ }^{1} G_{4}$ levels. The ESE spectra were recorded around $650 \mathrm{~nm}$, in a wavelength domain where a strong] ESA line responsible for photon avalanche in this material should appear ${ }^{2}$. By comparing the positions of the lines appearing in these spectra with the ones expected, from the energy level scale in this material, for ${ }^{3} \mathrm{H}_{4} \rightarrow{ }^{1} \mathrm{D}_{2}$ (large bars in the figures) and $\mathrm{F}_{4} \rightarrow{ }^{1} \mathrm{G}_{4}$ (small bars in the figures) excited state absorption (ESA) transitions, it seems clear that the former dominates. This was confirmed further by delaying the probe beam by a few $\mu s$ with respect to the pump beam since in this case the signal disappeared gradually and immediately. Indeed if the lines around $650 \mathrm{~nm}$ were assigned to ${ }^{3} \mathrm{~F}_{4}>\mathrm{G}_{4}$ ESA transitions, then, because of the $210 \mu \mathrm{s}$ feeding time of the ${ }^{3} \mathrm{~F}_{4}$ metastable state after ${ }^{3} \mathrm{H}_{4}$ excitation [3] the ESE signal would increase with the time delay between the two laser pulses. This result is very surprising since the model proposed by the authors of Ref. 1 to account for their photon avalanche process only included the possibility of a ${ }^{3} F_{4}>{ }^{1} G_{4}$ ESA transition. We have already planned to work on crystals doped by different amounts of $\mathrm{Tm}^{3+}$ ions and by pumping them in different excited states to clarify this question.

Acknowledgments: Thanks are expressed to $\mathrm{C}$. Borel and Ch. Wyon (LETI-CEA Grenoble) and N. Garnier (Labo. TSI, St Etienne) for their assistance in this research.

\section{Reference:}

1. H. Ni and S.C. Rand; Opt. Lett. 16, 1424 (1993)

2. M.J. Weber

3. R. Moncorgé, H. Manaa, M. Koselja, G. Boulon, C. Madej, J.C. Souriau, C. Borel, Ch. Wyon; this Proccedings, paper MP 30
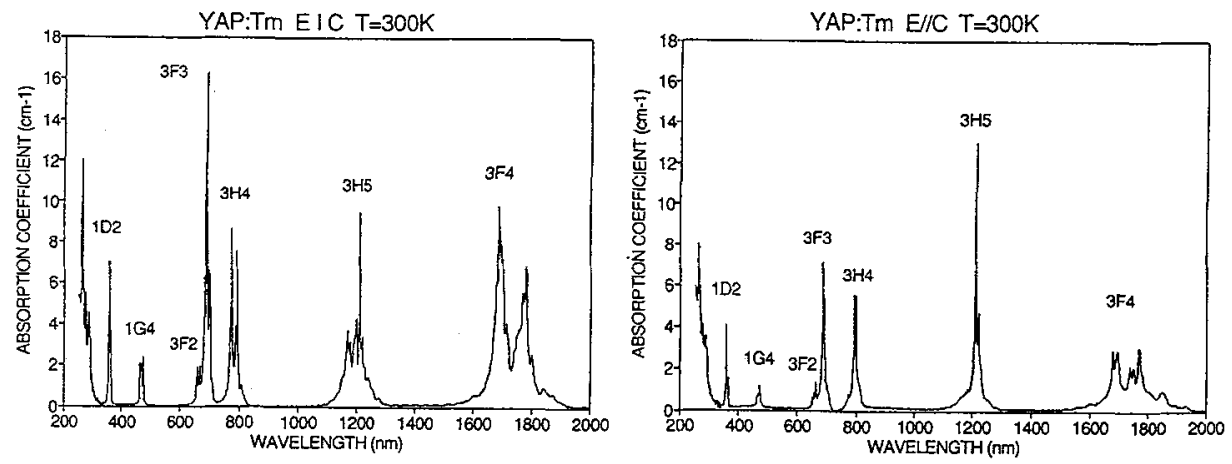

Figure 1: Room temperature absorption spectra parallel $(\pi)$ and perpendicular $(\sigma)$ to the $c$ axis of the crystal

of YAP:Tm ${ }^{3+}$ for light polarized 


\begin{tabular}{|c|c|c|c|c|c|}
\hline TRANSTION & $\begin{array}{c}\text { Average } \\
\text { wavelength } \\
\text { (nm) }\end{array}$ & Aed $\left(s^{-1}\right)$ & $A_{\operatorname{md}\left(s^{-1}\right)}$ & $\tau_{R}(\mathrm{~ms})$ & $\beta_{R}$ \\
\hline $3 \mathrm{~F}_{4} \rightarrow 3 \mathrm{H6}$ & 1800 & 225.1 & 0 & 4.44 & 1 \\
\hline $\begin{aligned} 3 \mathrm{H} 5 & \rightarrow 3 \mathrm{H} 6 \\
& 3 \mathrm{~F} 4\end{aligned}$ & $\begin{array}{l}1205 \\
3645\end{array}$ & $\begin{array}{c}289.7 \\
4\end{array}$ & $\begin{array}{r}109.3 \\
0.3\end{array}$ & 2.48 & $\begin{array}{l}0.99 \\
0.01\end{array}$ \\
\hline $\begin{array}{r}3 \mathrm{H} 4 \rightarrow 3 \mathrm{H} 6 \\
3 \mathrm{~F} 4 \\
3 \mathrm{H} 5\end{array}$ & $\begin{array}{r}800 \\
1440 \\
2380\end{array}$ & $\begin{array}{r}887.8 \\
106.8 \\
46.7\end{array}$ & $\begin{array}{c}0 \\
27.3 \\
10.7\end{array}$ & 0.92 & $\begin{array}{l}0.82 \\
0.12 \\
0.05\end{array}$ \\
\hline $\begin{array}{r}\mathrm{F3} \rightarrow 3 \mathrm{H6} \\
3 \mathrm{~F} 4 \\
3 \mathrm{H} 5 \\
3 \mathrm{H} 4\end{array}$ & $\begin{array}{r}700 \\
1145 \\
1670 \\
5600\end{array}$ & $\begin{array}{r}2912.3 \\
62.5 \\
193.5 \\
4.59 \\
\end{array}$ & $\begin{array}{c}0 \\
82.4 \\
0 \\
0.27\end{array}$ & 0.30 & $\begin{array}{l}0.89 \\
0.04 \\
0.06 \\
=0\end{array}$ \\
\hline $\begin{array}{r}F 2 \rightarrow 3 H 6 \\
3 F 4 \\
3 H 5 \\
3 H 4 \\
\end{array}$ & $\begin{array}{r}665 \\
1054 \\
1483 \\
3940 \\
\end{array}$ & $\begin{array}{c}675.5 \\
309.2 \\
350.5 \\
11.44 \\
\end{array}$ & $\begin{array}{l}0 \\
0 \\
0 \\
0\end{array}$ & 0.74 & $\begin{array}{l}0.50 \\
0.23 \\
0.26 \\
E 0\end{array}$ \\
\hline $\begin{array}{r}\mathrm{GA} \rightarrow 3 \mathrm{H6} 6 \\
3 \mathrm{F4} \\
3 \mathrm{H5} \\
3 \mathrm{H4} \\
3 \mathrm{H3} \\
3 \mathrm{~F} 2 \\
\end{array}$ & $\begin{array}{r}474 \\
643 \\
781 \\
1163 \\
1468 \\
1650 \\
\end{array}$ & $\begin{array}{r}1075.2 \\
201.1 \\
534.3 \\
142.3 \\
69.6 \\
24.8 \\
\end{array}$ & $\begin{array}{c}0 \\
14.9 \\
156 \\
39.9 \\
4.4 \\
0\end{array}$ & 0.44 & $\begin{array}{l}0.47 \\
0.09 \\
0.3 \\
0.08 \\
0.03 \\
0.01\end{array}$ \\
\hline $\begin{array}{r}1 \mathrm{D} 2 \rightarrow 3 \mathrm{H6} \\
3 \mathrm{~F} 4 \\
3 \mathrm{HS} \\
3 \mathrm{H4} \\
3 \mathrm{F3} \\
3 \mathrm{F2} \\
\text { 1G4 }\end{array}$ & $\begin{array}{r}360 \\
450 \\
513 \\
654 \\
741 \\
784 \\
1496 \\
\end{array}$ & $\begin{array}{c}17564 \\
7098 \\
122.8 \\
1031.9 \\
697 \\
1615.9 \\
158.3 \\
\end{array}$ & $\begin{array}{c}0 \\
0 \\
0 \\
0 \\
119 \\
70.1 \\
0\end{array}$ & 0.035 & $\begin{array}{l}0.61 \\
0.25 \\
80 \\
0.03 \\
0.02 \\
0.06 \\
=0\end{array}$ \\
\hline
\end{tabular}

\begin{tabular}{|c|c|c|c|}
\hline YAP: $\mathrm{Tm}^{3+}$ & $1 \%$ & $5 \%$ & $10 \%$ \\
\hline$\tau\left({ }^{1} \mathrm{D}_{2}\right)$ & $17 \mu \mathrm{s}$ & $5 \mu \mathrm{s}$ & - \\
\hline$\tau\left({ }^{1} \mathrm{G}_{4}\right)$ & $59 \mu \mathrm{s}$ & $23 \mu \mathrm{s}$ & - \\
\hline$\tau\left({ }^{3} \mathrm{H}_{4}\right)$ & $414 \mu \mathrm{s}$ & $290 \mu \mathrm{s}$ & $3.2 \mu \mathrm{s}$ \\
\hline$\tau\left({ }^{3} \mathrm{~F}_{4}\right)$ & $4.4-4.9 \mathrm{~ms}$ & $2.04 \mathrm{~ms}$ & $730 \mu \mathrm{s}$ \\
\hline
\end{tabular}

Table 2: 1/e fluorescence time constants of the emissions originating from the various eneggy levels in $\mathrm{Tm}^{3+}$ doped YAP for various $\mathrm{Tm}^{3+}$ concentrations

Table 1: Transitions, average wavelengths, electric and magnetic dipole transition probabilities, radiative lifetimes and branching ratios in YAP:Tm

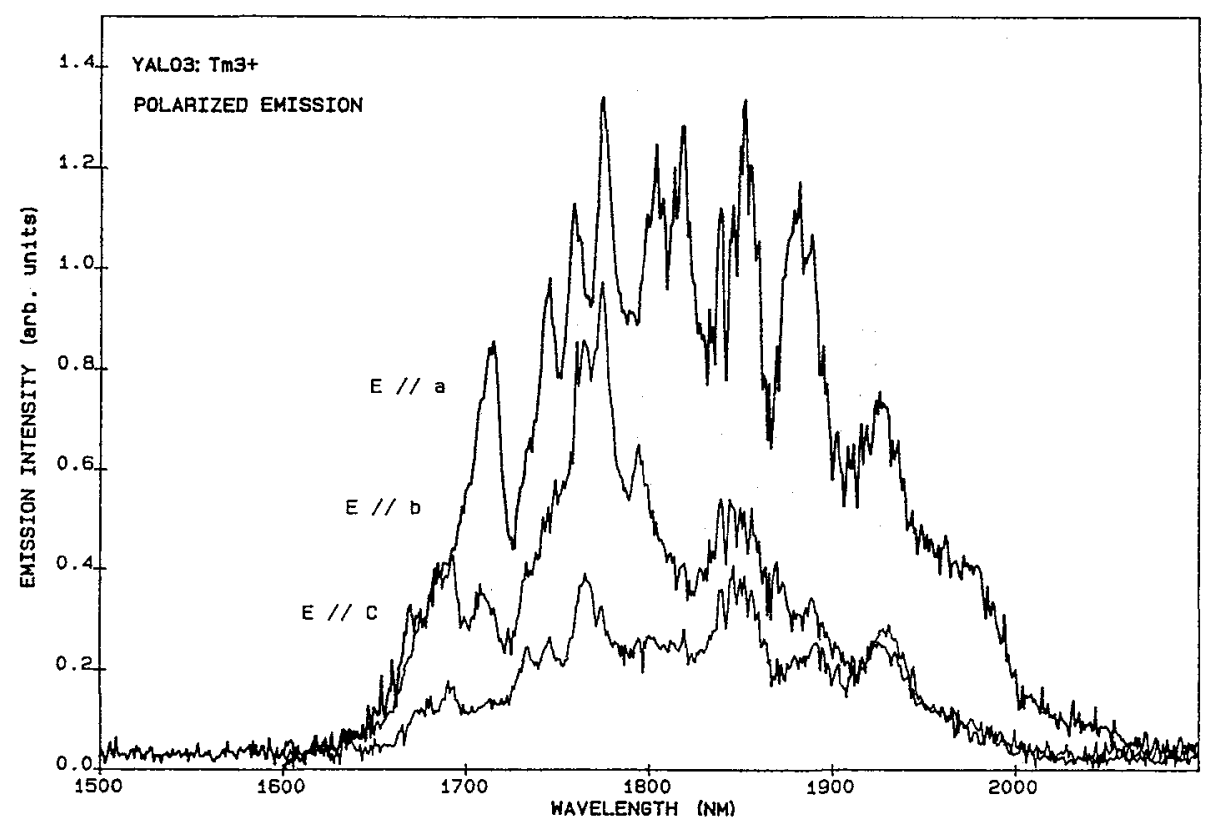

Figure 4. Room temperature calibrated and polarized infrared emission spectra of a $5 \%$ $\mathrm{Tm}^{3+}$ doped crystal 


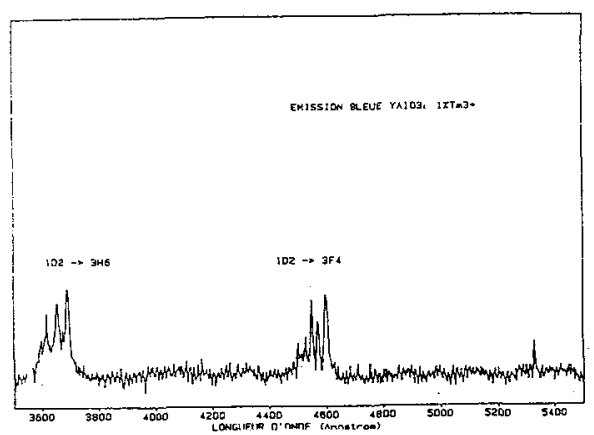

Figure 2: Room temperature visible emission spectra of a $1 \% \mathrm{Tm}^{3+}$ doped YAP powder sample obtained after $355 \mathrm{~nm}$ excitation

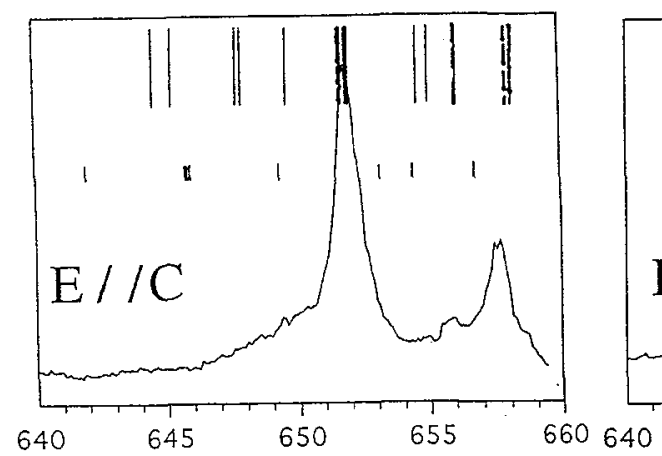

640

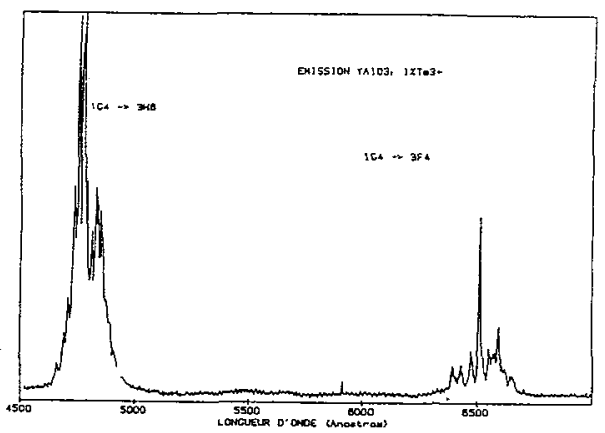

Figure 3: Room temperature visible emission spectra of a $1 \% \mathrm{Tm}^{3+}$ doped YAP powder sample obtained after $470 \mathrm{~nm}$ excitation

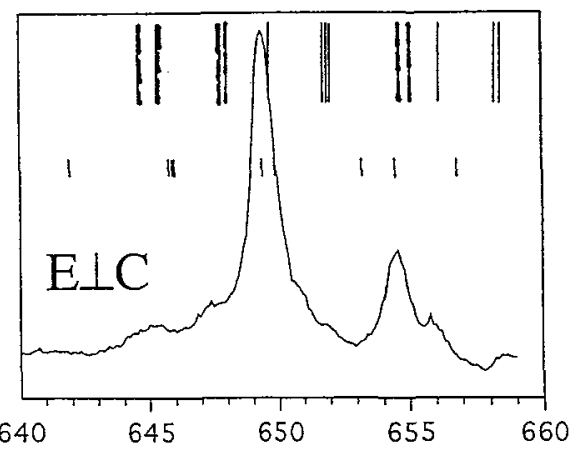

Figure 5: Room temperature ESE spectra recorded

with a $5 \% \mathrm{Tm}^{3+}$ doped YAP sample and comparison

with the expected positions of the lines

corresponding to the ${ }^{3} \mathrm{H}_{4} \rightarrow \mathrm{D}_{2}$ (large bars) and

$3_{F_{4} \rightarrow{ }^{1} G_{4}}$ ESA transitions. (a) $\pi$ polarization,

(b) $\sigma$ polarization 